\title{
Center for Agro Based Industry Promotes Green Industry Policy by Providing Technical Services Related with ISO 50001:2011
}

\author{
Enggar Kusuma Dewi Pamungkas ${ }^{\mathrm{a} *}$, Yuniarti ${ }^{\mathrm{a}}$, Sardjono $^{\mathrm{a}}$ \\ ${ }^{a}$ Center for Agro Based Industry, Ministry of Industry \\ Jl. Ir. H. Juanda No. 11, Bogor 16122, West Java, Indonesia
}

\begin{abstract}
Energy, specifically that use fossil fuels, has play a massive roles in the industry. Therefore, the sustainability of energy will determine the success of the national industry development in the future. ISO 50001:2011 provides organization with management strategies to increase energy efficiency, improve energy performance using a systematic approach and thus reduce costs. This standard is an effective guideline for organization to identify and achieve continual improvements on energy management systems. As a technical institution attached to Ministry of Industry, Center for Agro Based Industry (CABI) takes an important roles to provide technical services regarding implementation of ISO 50001:2011 in industry. CABI has started the initiate stages by preparing certified personnel and thus improving their skill. Nevertheless, CABI has some difficulties regarding lack of cooperation with related parties which is affecting the experiences from those personnel and the preparation stages for providing technical services to industry.
\end{abstract}

Keywords: energy management; energy efficiency in industry; sustainability; standard ISO 50001:2011

\section{Introduction}

For centuries, human society has a large dependency on fossil resources which are not only the primary feedstock for liquid fuels but also the basis for most of the industries (e.g. chemicals and polymers). Specifically, industry in Indonesia takes more than $44.2 \%$ of total energy consumption [1]. However, its depletion and environmental issues have driven the development of research for new renewable energy feed stocks that can replace fossil fuel resources.

\footnotetext{
* Corresponding author. Tel.: +62 8129034 0170; fax: +62 2518323339.

E-mail address: enggar@kemenperin.go.id
} 
Subsequently, it is also important to consider the efficient energy usage as a short term solution for those issues based on energy conservation principle.

Indonesian Government has shown a great concern on energy for the last decade. The government even clearly endorsed the policy by publishing Law on Energy in 2007 [2]. Furthermore, energy conservation by energy management is a mandatory for industry that consume energy equal and/or above than $6000 \mathrm{TOE} / \mathrm{year}[3,4]$. As industry consumed the majority of energy consumption, the government, specifically MoI takes focus on seven major industries: steel, cement, fertilizer, ceramic, pulp and paper, textiles and palm oil processing industries [5]. Subsequently, MoI focus on the establishment and development of green industry where one of its criteria is that all production processes must give priority to the efficiency and effectiveness in energy usage [6].

ISO 50001:2011 is a designed method to promote energy management systems. By using PDCA (Plan Do Check Act) principles, ISO 50001:2011 can be used in an organization as a guideline to achieve a continuous improvement on energy management systems. Nevertheless, majority of industries in Indonesia still use obsolete technology that has low efficiency while government has not provided subsidies supporting green industry policy yet. Based on the 'Penghargaan Industri Hijau' awardee list in 2013, which was held by Ministry of Industry, PT. Argo Pantes and PT. Indah Kiat were already certified with ISO 50001:2011. The small number of industry that has been certified might be caused by some constraints, specifically related with the awareness and readiness of industry, government institution and related parties to establish and enhance the application of ISO 50001:2011. Therefore, technical ministry; MoI and MEMR have responsibility to promote the implementation of this standard in national industries.

\section{Material and method}

\subsection{Material}

2.2. Method

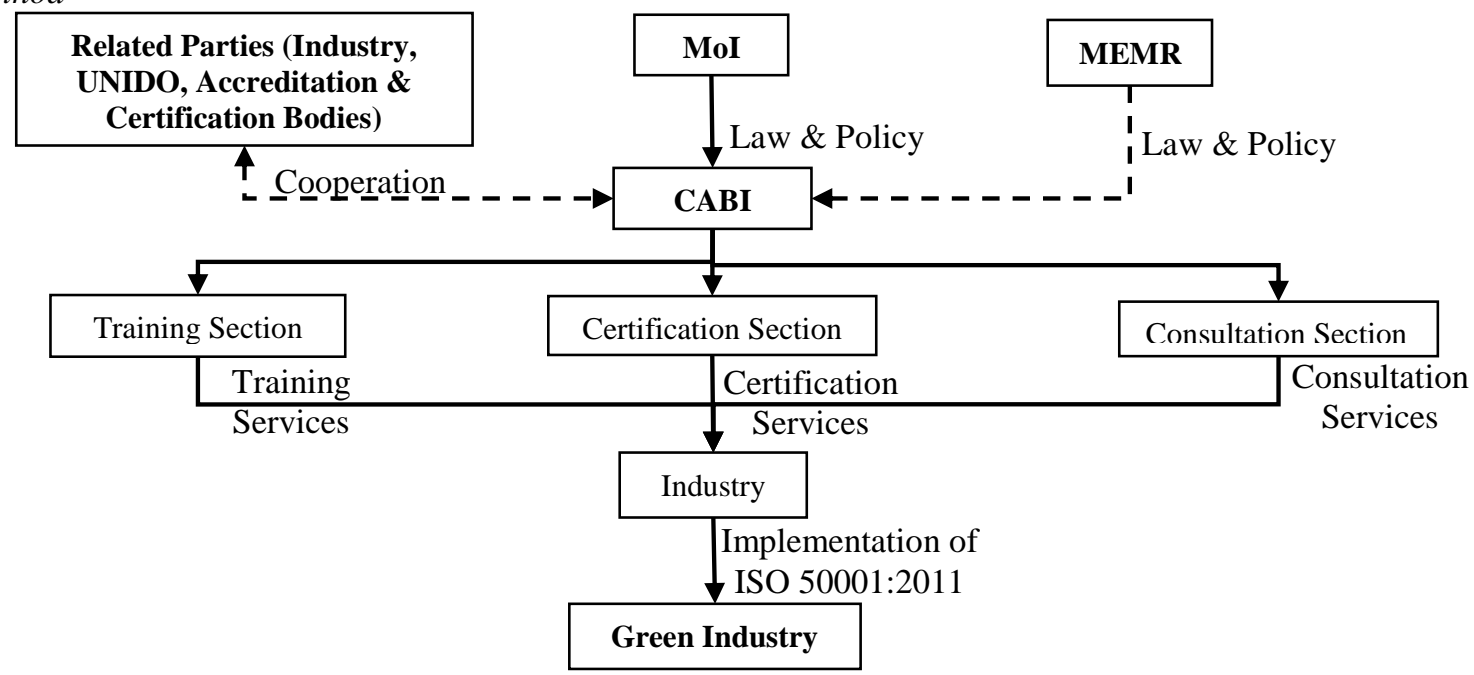

Figure 1. Proposed Framework by CABI

CABI as a professional institution attached to MoI has a commitment to support government policy and help industry achieving the require targets in energy conservation. In addition, CABI took this issue as an opportunity to add the scope of its service by providing technical services needed by industry. Herewith, CABI adjust a framework 
as a guideline in the establishment of an excellent institution providing technical services related with ISO 50001:2011 (Figure 1).

\section{Results and discussion}

Based on the proposed framework, CABI has set an action plan which is consist of a specific roadmap (Figure 2) and an activity timeline (Table 1). It is important to mention that CABI will be focused to establish service in training section first before going to establish consultation and certification services in 2015 .

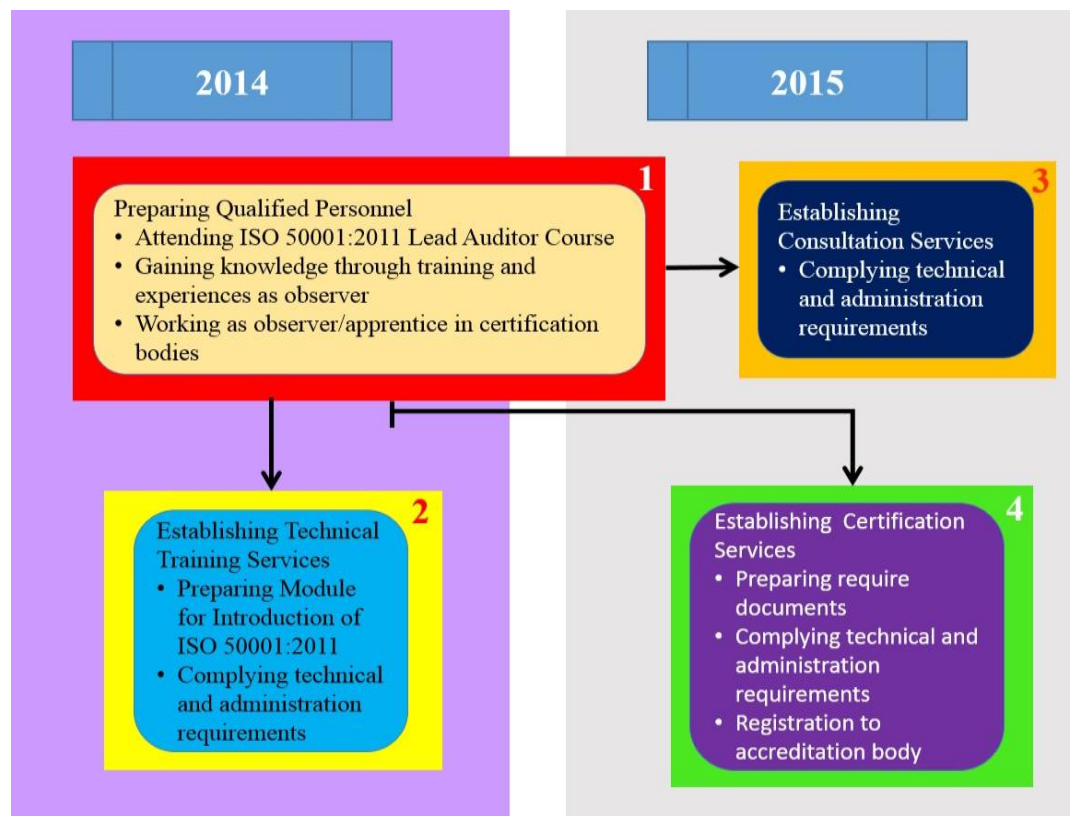

Figure 2. Roadmap for establishing CABI as Center for ISO 50001:2011.

During the initial stage, CABI took focus on developing its human resources. 10 chosen people were trained in ISO 50001:2011 Lead Auditor training course and 9 people were already passed the course. Furthermore, CABI is looking for an opportunity to cooperate with related party (i.e. certification institutions) to give those personnel opportunities getting involve in some pilot projects as observers and gain some experiences needed to be qualified auditor. CABI has tried to contact BSI Group Indonesia and TUV Rheiland, which have already had some clients and done certification services regarding ISO 500001:2011. This activity is intended to give opportunity to the personnel working as an observer and/or apprentice in a specific timeline (See Table 1). In addition, it is needed to improve personnel's technical skills and awareness of constraints and/or opportunity regarding implementation ISO 50001:2011 in depth. However, there was some issues that has not been resolved yet with both parties. Therefore, CABI is trying to directly contact industry that has implement ISO 50001:2011 into their organization and thus looking for a mutual partnership in cooperate projects. In addition, an approach by having a collaboration with an association might be considered to give a better access as there are not too many industry that have set this standard within their organization. This is due to the fact that ISO 500001:2011 is not compulsory to be implemented yet for all industries and the lack of management's awareness, competency of human resources and/or limited financial budget to employ this standard in the industry. 
It can be seen from Table 1. That CABI sets most of the timeline to prepare and increase the competency of those personnel as qualified human resources is the most important factor in this project. CABI gives opportunitiesto take part in training, seminar or other activities that can raise their skills \& knowledge, such as: training that been held by MoI, MEMR, UNIDO and short course conducted by University of Twente, The Netherlands.

Table 1. Timeline for the proposed framework.

\begin{tabular}{|c|c|c|c|c|c|c|c|c|c|c|c|c|c|c|c|c|c|c|c|}
\hline \multirow{2}{*}{ No - } & \multirow{2}{*}{ Activities } & \multicolumn{10}{|c|}{2014} & \multicolumn{8}{|c|}{2015} \\
\hline & & Mar & Apr & May & Jun & Jul & Ags & Sep & Oct & Nov & Dec & Jan & Feb & Mar & Apr & May & Jun & Jul & Ags \\
\hline 1 & Training course & $\sqrt{ }$ & & & & & & & & & & & & & & & & & \\
\hline 2 & Assessment of cooperation plan & & $\sqrt{ }$ & $\sqrt{ }$ & & & & & & & & & & & & & & & \\
\hline 3 & $\begin{array}{l}\text { Participation in training and } \\
\text { working as observer }\end{array}$ & & & $\sqrt{ }$ & $\sqrt{ }$ & $\sqrt{ }$ & $\sqrt{ }$ & $\sqrt{ }$ & $\sqrt{ }$ & $\sqrt{ }$ & $\sqrt{ }$ & $\sqrt{ }$ & $\sqrt{ }$ & $\sqrt{ }$ & & & & & \\
\hline 4 & Working as an apprentice & & & & & & & & & $\sqrt{ }$ & $\sqrt{ }$ & $\sqrt{ }$ & $\sqrt{ }$ & $\sqrt{ }$ & & & & & \\
\hline 5 & $\begin{array}{l}\text { Preparation of module for training } \\
\text { Introduction of ISO 50001:2011 }\end{array}$ & & & $\sqrt{ }$ & $\sqrt{ }$ & $\sqrt{ }$ & $\sqrt{ }$ & $\sqrt{ }$ & & & & & & & & & & & \\
\hline 6 & $\begin{array}{l}\text { Fulfill requirements for training } \\
\text { services }\end{array}$ & & & & & & $\sqrt{ }$ & $\sqrt{ }$ & & & & & & & & & & & \\
\hline 7 & Evaluation & & & & & & & $\sqrt{ }$ & $\sqrt{ }$ & & & & & & & & & & \\
\hline 8 & $\begin{array}{l}\text { Fulfill requirements for } \\
\text { consultation services }\end{array}$ & & & & & & & & & & & & $\sqrt{ }$ & $\sqrt{ }$ & $\sqrt{ }$ & $\sqrt{ }$ & & & \\
\hline 9 & Evaluation & & & & & & & & & & & & & & & $\sqrt{ }$ & $\sqrt{ }$ & & \\
\hline 10 & Preparation of require documents & & & & & & & & & & & & $\sqrt{ }$ & $\sqrt{ }$ & $\sqrt{ }$ & $\sqrt{ }$ & & & \\
\hline 11 & $\begin{array}{l}\text { Fulfill requirements for } \\
\text { certification services }\end{array}$ & & & & & & & & & & & & & & & $\sqrt{ }$ & $\sqrt{ }$ & & \\
\hline 12 & Registration to accreditation body & & & & & & & & & & & & & & & & & $\sqrt{ }$ & \\
\hline 13 & Evaluation & & & & & & & & & & & & & & & & & $\sqrt{ }$ & $\sqrt{ }$ \\
\hline
\end{tabular}

Furthermore, CABI will prepare the relevant sections (training, certification and consultation) to meet the technical and administration requirements in order to provide services independently in the future. Herewith, CABI can provide technical services in order to meet market needs. It can be seen from both Figure 2 and Table 1 that CABI will take focus on the establisment of training service first before do similar procedure for the other services afterward. This is due to the fact that CABI consider raising of industry's awarenes is a fundamental step to support the implementation of this standard. In addition, qualified personnel with higher level of experiences \& competency will be needed for both consultation and certification services. Therefore, it takes a longer time with more effort to prepare both services. Nevertheles, it is also important to mention that the National Accreditation Committe in Indonesia are not able to give an accreditation to certification institution on ISO 50001:2011 yet, therefore CABI takes the establishment of certification service in the last stage.

Based on the Table 1, it can be seen that CABI is in the developing qualified personnel phase (action plan no 2, 3, 4 and 5). However, as already mentioned aboved that this stage has encountered some issues which is mainly caused by the partnership that has not been established yet with related parties, i.e.: certification bodies, industry and association. It is also important to mention that the module preparation has been delayed to August until November 2014, while the documents must be finished before in the end of this year. Nevertheless, the training service is still expected to be on the schedule and can be started in the early of 2015. On the other hand, this issues might give a detrimental effect for the establishment of consultation and certification services.

\section{Conclusion}

ISO 50001:2011 is a fundamental method that can be used to promote energy conservation in industry. The government might be able to encourage the implementation of this standard by issuing obligatory regulations, providing financial assistance and supporting related institutions, i.e.: training, consultation and/or certification bodies. CABI has committed to provide the technical services needed by industry to implement ISO 50001:2011 in 
their organization and thus promote the green industry policy. However, CABI faces some constraints in the preparation stages due to the lack of communication (i.e. partnership) with related parties and the unreadiness from industries to apply ISO 50001:2011 in its organization. Therefore, the establishment of CABI as center for energy management services might be delayed and thus affect the government's target regarding energy conservation for industry.

\section{Acknowledgements}

The authors would like to thank Mr. Yang Yang Setiawan (Secretary of Industrial Policy, Climate and Quality Research Agency) and Mrs. Rochmi Widjajanti (Director of CABI) for giving us opportunities to attend ISO 50001:2011 Lead Auditor Training Course and submit this paper to the $3^{\text {rd }}$ Indonesia EBTKE ConEx 2014.

\section{References}

[1] Haryono, T. Penerapan manajemen energi di Indonesia. SNI Valuasi 2013;7:30-32.

[2] Kementerian Energi dan Sumber Daya Mineral. Undang-undang Republik Indonesia No. 30 Tahun 2007 tentang Energi. Jakarta; 2007.

[3] Kementerian Energi dan Sumber Daya Mineral. Peraturan Pemerintah No. 70 Tahun 2009 tentang Konservasi Energi. Jakarta, 2009.

[4] Kementerian Energi dan Sumber Daya Mineral. Peraturan Menteri Energi dan Sumber Daya Mineral No. 14 Tahun 2012 tentang Manajemen Energi. Jakarta; 2012

[5] Biro Perencanaan, Kementerian Perindustrian. Perencanaan Kebutuhan Energi Sektor Industri Dalam Rangka Akselerasi Industrialisasi. Jakarta; 2012.

[6] Kementerian Perindustrian. Undang-undang Republik Indonesia No. 3 Tahun 2014 tentang Industri. Jakarta; 2014. 